\title{
The Understanding of the Image of God in the Early and Medieval Church History
}

\author{
Franklin Hutabarat, Reymand Hutabarat, and Deanna Beryl Majilang
}

\section{ABSTRACT}

It is only in the Bible whereby precise details in regards to humanity's origin from the conservative Christian point of view, are recorded. The Bible clearly states that in God's image, man was made (Gen 1:27). This statement reflects the belief that the essence of human beings was created in the likeness of God, and demonstrated that man did not merely turn out to be in God's image but was carefully crafted to be so. However, despite the exalted position of man among creatures, theologians still have questions and debates about the image of God is, and what does it consists of. Many scholars have wrestled with the precise sense of the image of God from the time of the Early Church until the Medieval Era. This research uses qualitative method, whereby the early works of the fathers of the medieval church are analyzed. The research is carried out on a descriptive basis. It is the aim of this research to offer a structural and systematic understanding of the image of God, based on the perception of the early church and medieval church fathers. As a result, a conclusion is formed.

Keywords: Image of God, church history, early church fathers; medieval church.
Published Online: November 16, 2021

ISSN: $2736-5514$

DOI: 10.24018/ejtheology.2021.1.6.12

\section{F. Hutabarat*}

Asia-Pacific International University, Muak Lek, Saraburi, Thailand.

(e-mail: fhutabarat@apiu.edu)

\section{R. Hutabarat}

Universitas Advent Indonesia, Bandung, Jawa Barat, Indonesia.

(e-mail: marasitua@yahoo.com)

D. Majilang

Asia-Pacific International University, Muak Lek, Saraburi, Thailand.

(e-mail: deanna@apiu.edu)

*Corresponding Author

\section{INTRODUCTION}

From the conservative Christian view point, only the Bible record gives accurate information about the origin of mankind (McGrath, 2017). The Bible clearly states in Genesis 1:27, whereby man was created in the image of God (Allen, 2020). This verse expresses that the thought of man's nature was made after the likeness of God, and shows that the human being did not merely turn out in the image of God, but was carefully designed to be such (Allen, 2020).

The fact that man was created in the image of God means that God assigned some of His attributes to be given to mankind. For example, man is able to reason; man has a mind, will and emotions, just as God does (Vanhoozer, 2013). The image of God shows man's resemblance to God, and God's resemblance to man. This resemblance was "man's resemblance to God's moral perfections which are communicable to His creatures" (Crisp, 2015).

It is also clear that in distinction from other creatures in this world, only man has been made in God's image, and "little less than God" (Crisp, 2015). Man is exalted above all creatures to the position next to God Himself. The ground for this exalted view of the worth of man is not primarily because of his superior nature, but because of his special relationship to God that set him apart from other creatures. This is clearly implied in the statement that God made man in His own image.he journal reserves the right to do the final formatting of your paper.

In spite of man's exalted position among the creatures, however, there are still questions and debates among the theologians on what the image of God is and what the image of God consists of (Bray, 1991). From the time of the Early Church up to the Medieval period, many scholars have wrestled with the precise meaning of the term image of God.

The research questions that lead this essay is: What is the meaning of image of God, and what the image of God consist of.

\section{Research Methodology}

This study conducts a qualitative research, whereby this study evaluates the works from the early church to the medieval church fathers. The analysis uses descriptive basis. This research studies carefully on the perception of these early and medieval church fathers on the Image of God, with the hope that this study can offer a structural and systematic understanding of the image of God. A conclusion will be formed, based on the analysis of these church fathers' thoughts. 


\section{Result AND DisCUSSION}

\section{A. Early Church}

In the Apostolic Fathers, there is nothing mentioned about the image of God in man. This section, therefore, deals from the time of the Post Apostolic Fathers up to the fifth century. The discussion is divided into two sections: Early Church Fathers and Medieval Century Fathers.

Though no Early Fathers focused their discussions on the image of God in man, some allusions are found in some of their writings. This section presents the concept of the image of God in man proposed by the four most outstanding early fathers. The early father are Ireneaus, Clement of Alexandria, Origen, and Tertulian.

\section{1) Ireneaus}

In the second century, Ireneaus asserted that only man who was "made spiritual and perfect" by reason "of the outpouring of the Spirit" was made "both in the image and in the likeness of God" (Stewart, 2014). According to Ireneaus, the man who is without the Spirit is psychical, carnal, and imperfect. Although in the man's formation he has the image of God, however man has not yet received the likeness which is given by the Spirit (Stewart, 2014).

He said that God created man in His image and after His likeness. Man's likeness to God, however, was lost in the Fall, whereas the image of God still remained. The lost likeness of God is being restored in believers in the process of redemption (Michael Heintz, 2008). Ireneaus stated:

"But if the Spirit be wanting to the soul, he who is such is indeed of an animal nature, and being left carnal, shall be an imperfect being, possessing indeed the image [of God] in his formation, but not receiving the similitude through the Spirit, and thus is this being imperfect" (Behr \& Behr, 2013).

This description is of man as he is after the Fall. Fallen man, according to this statement, still possesses the image of God, but needs the work of the Spirit in order to have restored to him the similitude or likeness to God that he lost in the Fall. Ireneaus developed this point further.

"And then, again, this Word has manifested when the Word of God was made man, assimilating Himself to man, and man to Himself, so that by means of his resemblance to the Son, man might become precious to the Father. For in times long past, it was said that man was created after the image of God, but it was not [actually] shown; for the Word was as yet invisible, after whose image man was created. Wherefore also he did easily lose the similitude. When, however, the Word of God became flesh, He confirmed both these: for He both showed forth the image truly, since He became Himself what was His image; and He re-established the similitude after a sure manner, by assimilating man to the invisible Father through means of the visible Word" (Behr \& Behr, 2013).

Again Ireneaus said that though man was created in the image of God, man lost the similitude or likeness to God in the Fall. Christ, however, showed man in His own person what the image of God truly was.

For Ireneaus, the image of God meant man's "nature as a rational and free being, a nature which was not lost at the fall" ("The Writings of Irenaeus", 2018). But he also included man's freedom, his ability to make decisions, and his responsibility for these decisions, as parts of the image of God ("The Writings of Irenaeus," 2018). Both man's rationality and his freedom, according to Irenaeus, are retained even after the Fall.

Ireneaus understood likeness of God, in distinction from the image of God, as the "robe of sanctity" that the Holy Spirit had bestowed on Adam (Behr \& Behr, 2013). According to Ireneaus, the believer has three components in his being: body, soul, and spirit.

The unbeliever, however, has only soul and body. The Holy Spirit creates man's spirit as an organ whereby the believer receives the divine influence, and knows divine truth. The spirit - within the human being - is the bearer of the likeness of God. This likeness-bearing spirit was given to Adam before the Fall, was lost at the Fall, and is being restored in the process of redemption.

\section{2) Clement of Alexandria}

Clement of Alexandria was almost a contemporary of Irenaeus. His theology was developed in Alexandria about the end of the second century (Havrda, 2011). In some passages of his writings, the words image and likeness refer to two different things. According to Clement, image refers to the rationality which is universal in man, the power of reasoning, formally considered (Litwa, 2017). Clement, however, in some places did not make any distinction between "image" and "likeness" (Litwa, 2017). In such passages, it seemed Clement considered both the image and the likeness as the universal endowment of mankind. Clement used the two terms synonymously in vague reminiscence of the passages of Genesis (Havrda, 2011). 
There are also some passages in which Clement treated "image" and "likeness" as "synonyms, and ascribing both to the man who is in Christ" (Havrda, 2011). Another case is that the word "image" is used for the Christian who has received the mark of a Christian at baptism, while the word "likeness" is reserved for the Christian who is in the process of sanctification. In Clement's view, "a pious Christian" (AshwinSiejkowski, 2015) possesses not only the image, but also the likeness of God (Ashwin-Siejkowski, 2015). Thus, "likeness" refers to "a real resemblance to God, something going much beyond the formal resemblance of the image" (Ashwin-Siejkowski, 2015). According to Clement, "Christ was the first man to possess the likeness" (North, 2011), in which there is no physical element (North, 2011).

In spite of the inconsistency of the using of the word "image" and "likeness", Clement consistently related all men to the divine image. Man is described as the image, or as created in or according to it. In Clement's concept of God's image, there is also a sense in which the Christian is the image or likeness, and in which he is perfected through sanctification by Christ, who is Himself the image, and the likeness of God.

\section{3) Origen}

Origen expounded the interpretation of the image and likeness of God more fully. He contended that "the highest good is to become as near as like God as possible" (M. J. Edwards, 2017). In differentiating between the term "image" and "likeness", Origen drew attention to the fact that the word "likeness" occurred in conjunction with the word "image" in verse 26 of Genesis 1, but is omitted in verse 27. According to him, the silence of Moses concerning the "likeness" in verse 27 points that "man received the dignity of God's image at his first creation; but ... the perfection of his likeness was reserved for him at the consummation" (McInroy, 2011). The "likeness", then, was something for man to acquire for himself by his own earnest efforts to imitate God (M. Edwards, 2015).

In connection with the divine sonship of believers, Origen had an interesting passage. He stated that "every deed and word and thought of theirs, being formed by the only-begotten Word after his likeness, imitates the image of the invisible God" (Martens, 2012). The image of God in Christians is indirect, for it is the image of the Son who Himself is the image of God. Thus, the saint is an image of the Image. For the saints, the image of God involves being conformed to Christ who is in the body of glory and being transformed by the renewing of their minds - the refashioning in the likeness of Christ.

\section{4) Tertullian}

Through his copious writings, Tertullian was the real founder of Western theology (Gonzalez, 2013). Regarding the image of God in man, Tertullian —in discussing Bethesda's healing — asserted that humanity retained the image of God after sinning, and it could only be restored to the likeness of God through the renewing activity of the Holy Spirit. He wrote:

"An accession of efficacy was granted to the waters and to the angel. They who were wont to remedy bodily defects, now heal the spirit .... The guilt being removed too. Thus man will be restored for God to His 'likeness,' who in days by gone had been conformed to 'the image' of God; for he receives again that Spirit of God which he had then first received from His afflatus, but had afterward lost through sin" (North, 2011).

\section{B. Medieval Church}

Like the Early Fathers, those in the fourth and the fifth centuries did not pay much attention to the doctrine of the image of God. However, some concepts on the image of God subject are occasionally found in their writings. In this section, Gregory of Nyssa, John Chrysostom, Augustine, and Cyril of Alexandria are under discussion as representatives.

\section{1) Gregory of Nyssa}

Gregory of Nyssa sees all humanity as created according to the image of God, and every individual human being as created according to the image of God (Wickham, 2009). According to him, the image of God is reflected in "the very form of the body" of man (Meredith, 2012). He asserts that man's upright form and upward looks are marks of sovereignty which show his royal dignity derived from his constitution in the divine image (Wickham, 2009).

Gregory saw that there were several dimensions of the image of God in the human being. For example, he sees the image of God's kingship in human beings. Gregory stated:

"For as in our own life artificers shape a tool in the way appropriate to its use, so the best Artificer made our nature as it were a formation fit for the exercise of royalty, preparing it at once both by superior advantages of soul, and by the very form of the body, to be such as to be adapted for royalty: for the soul immediately shows its royal and exalted character, far removed as it is from the lowliness of private station, in that it has no lord, and is self-governed, swayed autocratically by its own will; for to whom 
else does this belong than to a king? And further, besides these facts, the fact that it is the image of that Nature which rules over all means nothing else than this, that our nature was created to be royal from the first. For as, in men's ordinary use, those who make images of princes both mould the figure of their form, and represent along with this the royal rank by the vesture of purple, and even the likeness is commonly spoken of as 'a king,' so the human nature also, as it was made to rule the rest was, by its likeness to the King of all, made as it were a living image, partaking with the archetype both in rank and in name not vested in purple, nor giving indication of its rank by scepter and diadem ... but instead of the purple robe, clothed in virtue, which is in truth the most royal of all raiment, and in place of the scepter, leaning on the bliss of immortality, and instead of the royal diadem, decked with the crown of righteousness; so that it is shown to be perfectly like to the beauty of its archetype in all that belongs to the dignity of royalty" (Meredith, 2012).

In another place, Gregory sees the image of God as mind and word He stated:

"And if you were to examine the other points also by which the Divine beauty is expressed, you will find that to them to the likeness in the image which we present is perfectly preserved. The Godhead is mind and word: for "in the beginning was the Word" and the followers of Paul "have the mind of Christ" which "speaks" in them: humanity too is not far removed from these: you see in yourself word and understanding, an imitation of the very Mind and Word." (Brill Dict. Greg. Nyssa, 2010).

Again, based on John's declaration, Gregory pointed out “love" as another aspect of God's image:

“'Love is of God', and 'God is love': the Fashioner of our nature has made this to be our feature too: for 'hereby,' He says, 'shall all men know that ye are my disciples, if ye love one another':--thus, if this be absent, the whole stamp of the likeness is transformed." (Meredith, 2012).

\section{2) John Chrysostom}

John Chrysostom was one of the most eloquent Eastern Church Fathers in the fourth and fifth centuries. For Chrysostom, the image of God in man is the dominion over the earth. According to him, man is called an image of God to show that there is a resemblance between God and man in his dominion over the creatures. He stated: "And yet, in that man is called an image, its showeth resemblance, as in man. For what God is in Heaven, that man is on earth, I mean as to dominion. And as he hath power over all things on earth, so also hath God power over all things which are in heaven and which are on earth" (Mayer \& Allen, 2017).

In this passage, Chrysostom pointed out that, as to dominion, there is similarity and dissimilarity between man and God. While God has power over all things in heaven as well as all things here on earth, man has power only over those here on earth. For Chrysostom, this resemblance of dominion constitutes the image of God in man.

\section{3) Augustine}

Augustine too, like Ireneaus, distinguished between the image and the likeness (Alexander Hernandez, 2016). He saw God's image in man as an endowment of God. He stated: "When God made man according to His own image, He gave him a soul so endowed with reason and intelligence that it ranks man higher than all the other creatures of the earth, the sea, the air, because they lack intelligence" (Michael Heintz, 2008).

He believed that the image must be defined as the power to remember God, the power to understand and love Him, and the power to be a partaker of Him (Blackburn, 2010). He called those powers as the trinity of the mind, and understood this trinity of the mind as God's image. It is not because the mind remembers, understands, and loves itself, but because it has the power to remember, understand, and love its maker (Blackburn, 2010).

Augustine perceived that the image of God is a property of the interior man, which is of the mind, and not of the body. Thus, for him, the image of God is "immortally impressed in the immortal nature of the soul" (Cavadini, 2013). Furthermore, he stated, "Let the mind remember its God, in whose image it was made, let him understand him and love him" (Blackburn, 2010).

According to Augustine, although the image in man has worn out and defaced by losing the participation of God, it still remains (Alexander Hernandez, 2016). Heintz wrote: "The mind is God's image... It still remains the image of God, although an image faded and defaced by the loss of that participation. It is in virtue of the fact that it has a capacity for God and the ability to participate in God, that it is his image. Only because it is his image can so high a destiny to be conceived for it. Here then is the mind, remembering itself, understanding itself, loving itself. Perceiving this, we perceive a trinity - a trinity still less than God but already an image of God." (Michael Heintz, 2008). 
Augustine emphasized that man is not only the image of one God, but also that of the triune God inasmuch as in man "his spirit, love, and knowledge are three things, and these three are one, and, when perfect, are equal "(Alexander Hernandez, 2016). This is why he sees the image in man as a trinity similarly in God, arguing that there is one essence in man with three equal substances which are love, understanding, and mind.

\section{4) Cyril of Alexandria}

According to Cyril, man is "created in God's image and likeness" (Van Loon, 2015). He believed the two terms - image and likeness - were identical (Van Loon, 2015). For Cyril, the image of God — in which man was created - is man's free will. But because of man's disobedience to God, the image of God in man became spoiled, and man is no longer able to freely communicate with God's love (Crawford, 2013). Furthermore, Cyril considered that the divine image in human beings had various facets such as "reason, freedom, dominion, sanctification, incorruptibility, and sonship" (Crawford, 2013).

\section{Middle Ages}

During the middle ages, the doctrine of the image of God was not so widely discussed. However, there are some references that provide several valuable information. Among them are John of Damascus in the 8th century, and Thomas Aquinas in the thirteenth century. They were the most outstanding.

\section{1) John of Damascus}

John of Damascus emphasized "intelligence", free will, and virtue as the components of the image, and his definitions of these three continued to be quoted as orthodox doctrine. According to John, "the image consisted of the human reason and spirit" (Adrahtas, 2015). He wrote "the phrase 'according to His image' clearly refers to the side of his nature which consists of mind and free will, whereas 'according to His likeness' means likeness in virtue so far as that is possible" (Louth, 2018).

However in John's understanding, all of these qualities find their fullest expression in the Logos as "the substantial image of God", through whom "the image of archetypical humanity could be said to have its reality" (Adrahtas, 2015).

\section{2) Thomas Aquinas}

In his view of the image of God in man, Thomas Aquinas adopted what Augustine had taught. He also made the concept more explicit, and modified it to fit into his own elaborate system. According to Thomas, the image of God is found primarily in man's intellect or reason. Only intelligent_creatures can be said to be created in God's image (te Velde, 2017). Since Thomas finds the image of God particularly in man's intellect, it is clear that for him the intellect is the most Godlike quality of man.

Aquinas divided God's image in man into three stages. He wrote: "God's image can be considered in man at three stages: the first stage is man's natural aptitude for understanding and loving God, an aptitude which consists in the very nature of the mind, which is common to all men. The next state is where a man is actually or dispositively knowing and loving God, but still imperfectly; and here we have the image by conformity of grace. The third stage is where a man is actually knowing and loving God perfectly; and this is the image by likeness of glory ... The first stage of image ... is found in all men, the second only in the just, and the third only in the blessed." (te Velde, 2017).

According to Aquinas, God's image remains always in the mind "whether this image of God is so faint shadowy, . . . as in those who lack the use of reason; or whether it is dim and disfigured, as in sinners; or whether it is bright and beautiful, as in the just" (das Neves \& Vaccaro, 2013). Therefore, "intellectual creatures alone, properly speaking, are made in God's image" (das Neves \& Vaccaro, 2013). And man is in the image of God, because he, like God, is rational. In conclusion, for Aquinas, the image of God is (1) primarily, the intellectual nature endowed at Creation which has been partially lost; and (2) conformity to grace and glory thus, man (only) has the image if he conforms (te Velde, 2017).

\section{CONCLUSION}

In the early stage of church history, the "image of God" in man was construed by the church fathers, such as Irenaeus, Clement of Alexandria, Origen, and Tertullian, to be the basic natural form of the human; while the "likeness of God" was understood by them as the supernaturally endowed function which exists in right relation to the Creator. Man's likeness to God was lost in the fall, whereas the image of God still remains. In the fourth and fifth centuries, various concepts of the image of God were suggested. For Gregory of Nyssa, the image of God is reflected in the physical form of man. Chrysostom understood it as the dominion over the earth. Augustine considered it as the power to remember, to understand, and to love God. He called these three powers the Trinity of the mind. The image of God, according to Augustine, is found not in human body, but in the human mind. 
In the Middle Ages, John of Damascus and Thomas Aquinas were the most outstanding figures who discussed the image of God in man. Both of them considered that the image of God is primarily man's intellectual things. They believe that the image of God is found in every human being. Therefore, the image of God is not found in irrational creatures.

\section{ACKNOWLEDGEMENT}

The first author would like to say thank you to Dr. Reymand Hutabarat, who contributes his analysis on the idea of the "Image of God" in the Middle Ages era, as well as his thoughtful comments throughout this research, and Deanna Beryl Majilang for her language, grammar and formatting expertise.

\section{REFERENCES}

Adrahtas, V. (2015). John of Damascus. In Wiley Blackwell Companion to Patristics. https://doi.org/10.1002/9781118438671.ch18. Alexander Hernandez, W. (2016). St. Augustine on Time. International Journal of Humanities and Social Science.

Allen, M. (2020). Systematic Theology and Biblical Theology-Part One. In Journal of Reformed Theology. https://doi.org/10.1163/15697312-bja10002.

Ashwin-Siejkowski, P. (2015). Clement of Alexandria. In Wiley Blackwell Companion to Patristics. https://doi.org/10.1002/9781118438671.ch5.

Behr, J., \& Behr, J. (2013). Against the Heresies. In Irenaeus of Lyons.https://doi.org/10.1093/acprof:oso/9780199214624.003.0003.

Blackburn, L. (2010). Augustine of Hippo: Philosopher, Exegete, and Theologian. Augustinian Studies. https://doi.org/10.5840/augstudies201041229.

Bray, G. (1991). The Significance of God'S Image in Man. Tyndale Bulletin.

Cavadini, J. C. (2013). Trinity and apologetics in the theology of St. Augustine. Modern Theology. https://doi.org/10.1111/moth.12001.

Adrahtas, V. (2015). John of Damascus. In Wiley Blackwell Companion to Patristics. https://doi.org/10.1002/9781118438671.ch18.

Alexander Hernandez, W. (2016). St. Augustine on Time. International Journal of Humanities and Social Science.

Allen, M. (2020). Systematic Theology and Biblical Theology-Part One. In Journal of Reformed Theology. https://doi.org/10.1163/15697312-bja10002.

Ashwin-Siejkowski, P. (2015). Clement of Alexandria. In Wiley Blackwell Companion to Patristics. https://doi.org/10.1002/9781118438671.ch5.

Behr, J., \& Behr, J. (2013). Against the Heresies. In Irenaeus of Lyons.https://doi.org/10.1093/acprof:oso/9780199214624.003.0003.

Blackburn, L. (2010). Augustine of Hippo: Philosopher, Exegete, and Theologian. Augustinian Studies. https://doi.org/10.5840/augstudies201041229.

Bray, G. (1991). The Significance of God'S Image in Man. Tyndale Bulletin.

Cavadini, J. C. (2013). Trinity and apologetics in the theology of St. Augustine. Modern Theology. https://doi.org/10.1111/moth.12001.

Crawford, M. R. (2013). Scripture as "one book": Origen, Jerome, and Cyril of Alexandria on Isaiah 29:11. Journal of Theological Studies. https://doi.org/10.1093/jts/fls175.

Crisp, O. D. (2015). On Original Sin. International Journal of Systematic Theology. https://doi.org/10.1111/ijst.12107.

das Neves, J. C., \& Vaccaro, A. (2013). Corporate Transparency: A Perspective from Thomas Aquinas' Summa Theologiae. Journal of Business Ethics. https://doi.org/10.1007/s10551-013-1682-6.

Edwards, M. (2015). Origen of Alexandria. In Wiley Blackwell Companion to Patristics. https://doi.org/10.1002/9781118438671.ch6.

Edwards, M. J. (2017). Origen against plato. In Origen Against Plato. https://doi.org/10.4324/9781315186993.

Gonzalez, E. (2013). Anthropologies of continuity: The body and soul in tertullian, perpetua, and early christianity. Journal of Early Christian Studies. https://doi.org/10.1353/earl.2013.0041.

Havrda, M. (2011). Grace and free will according to Clement of Alexandria. Journal of Early Christian Studies. https://doi.org/10.1353/earl.2011.0001.

Litwa, M. D. (2017). You Are Gods: Deification in the Naassene Writer and Clement of Alexandria. In Harvard Theological Review. https://doi.org/10.1017/S0017816016000419.

Louth, A. (2018). John of Damascus. In Encyclopedia of Medieval Philosophy. https://doi.org/10.1007/978-94-024-1151-5_602-1.

Martens, P. W. (2012). Origen and Scripture: The Contours of the Exegetical Life. In Origen and Scripture: The Contours of the Exegetical Life. https://doi.org/10.1093/acprof:oso/9780199639557.001.0001.

Mayer, W., \& Allen, P. (2017). John Chrysostom. In The Early Christian World. https://doi.org/10.4324/9781315165837.

McGrath, A. E. (2017). Theology: The basic readings. In Theology: The Basic Readings. https://doi.org/10.1002/9781119158196.

McInroy, M. J. (2011). Origen of Alexandria. In The Spiritual Senses: Perceiving God in Western Christianity. https://doi.org/10.1017/CBO9781139032797.004.

Meredith, A. (2012). Gregory of Nyssa. In Gregory of Nyssa. https://doi.org/10.4324/9780203006535.

Michael Heintz. (2008). The Fathers of the Church: A Comprehensive Introduction (review). Journal of Early Christian Studies. https://doi.org/10.1353/earl.0.0227.

North, J. L. (2011). Early Christian Thinkers: The Lives and Legacies of Twelve Key Figures (Paul Foster). Irish Theological Quarterly. https://doi.org/10.1177/0021140011416301d.

Stewart, A. E. (2014). Book Review: Reading the Early Church Fathers: From the Didache to Nicaea. Biblical Theology Bulletin: Journal of Bible and Culture. https://doi.org/10.1177/0146107914540491g.

te Velde, R. (2017). Aquinas on god: The "divine science" of the summa theologiae. In Aquinas on God: The "Divine Science" of the Summa Theologiae. https://doi.org/10.4324/9781315262291.

The Brill Dictionary of Gregory of Nyssa. (2010). In The Brill Dictionary of Gregory of Nyssa. https://doi.org/10.1163/ej.9789004169654.i-814.

The Writings of Irenaeus. (2018). In Irenaeus. https://doi.org/10.2307/j.ctt22nm648.5.

Van Loon, H. (2015). Cyril of Alexandria. In Wiley Blackwell Companion to Patristics. https://doi.org/10.1002/9781118438671.ch11.

Vanhoozer, K. J. (2013). Systematic theology. In The Routledge Companion to Modern Christian Thought. https://doi.org/10.4324/9780203387856. 
European Journal of Theology and Philosophy www.ej-theology.org

Wickham, L. (2009). Gregory of Nyssa. In Journal of Ecclesiastical History. https://doi.org/10.1017/S0022046908005976.

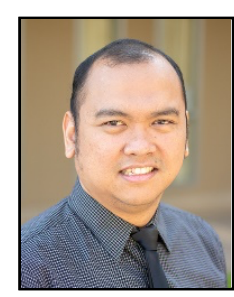

Franklin Hutabarat was born in Jakarta, Indonesia on December 30, 1983. He completed his Master of Theology in historical theology from the Adventist International Institute of Advanced Studies, Philippines and he earned his Doctor of Philosophy in religious studies from the Philippine Christian University.

He is currently serving as Theology lecturer at the Asia-Pacific International University in Thailand. Previously he taught at the Universitas Advent Indonesia and Manila Adventist College, respectively. He recently published an e-book entitled Introduction to Homiletics, Bookrix, 2021 and Church History, Bookrix, 2021. His main research interest is in the theology and doctrines.

Dr. Franklin Hutabarat is a member of the Society of Biblical Literature and Adventist Theological Society. 